\title{
THE LIMITS OF LANGUAGE
}





\section{THE LIMITS \\ OF LANGUAGE}

STEPHEN DAvid Ross

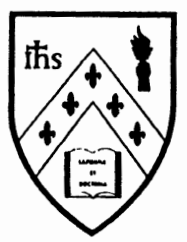

FORDHAM UNIVERSITY PRESS

New York 
Copyright $@ 1994$ by Fordham University Press

All rights reserved

LC 93-17970

ISBN 0-8232-1518-0 (clothbound)

Second printing 1996

Library of Congress Cataloging-in-Publcation Data

Ross, Stephen David

The limits of language / by Stephen David Ross

p. $\mathrm{cm}$.

Includes bibliographical references and index

ISBN 0-8232-1518-0 (cloth) : $\$ 32.00$

1. Language and languages-Philosophy. I. Title.

P106.R66 1994

93-17970

$401-\mathrm{dc} 20$

CIP

PUBLICATION OF THIS BOOK

WAS AIDED BY A GRANT FROM

THE HENRY AND IDA WISSMANN FUND 